\title{
Kemampuan Pemodelan Matematika Melalui Pendekatan Pendidikan Matematika Realistik Indonesia (PMRI) di SMK Yayasan Bakti Prabumulih
}

\author{
Monica Apriliana ${ }^{1}$, Lusiana, Jumroh \\ ${ }^{1}$ Universitas PGRI Palembang \\ ${ }^{1}$ Donaarsinta09@gmail.com
}

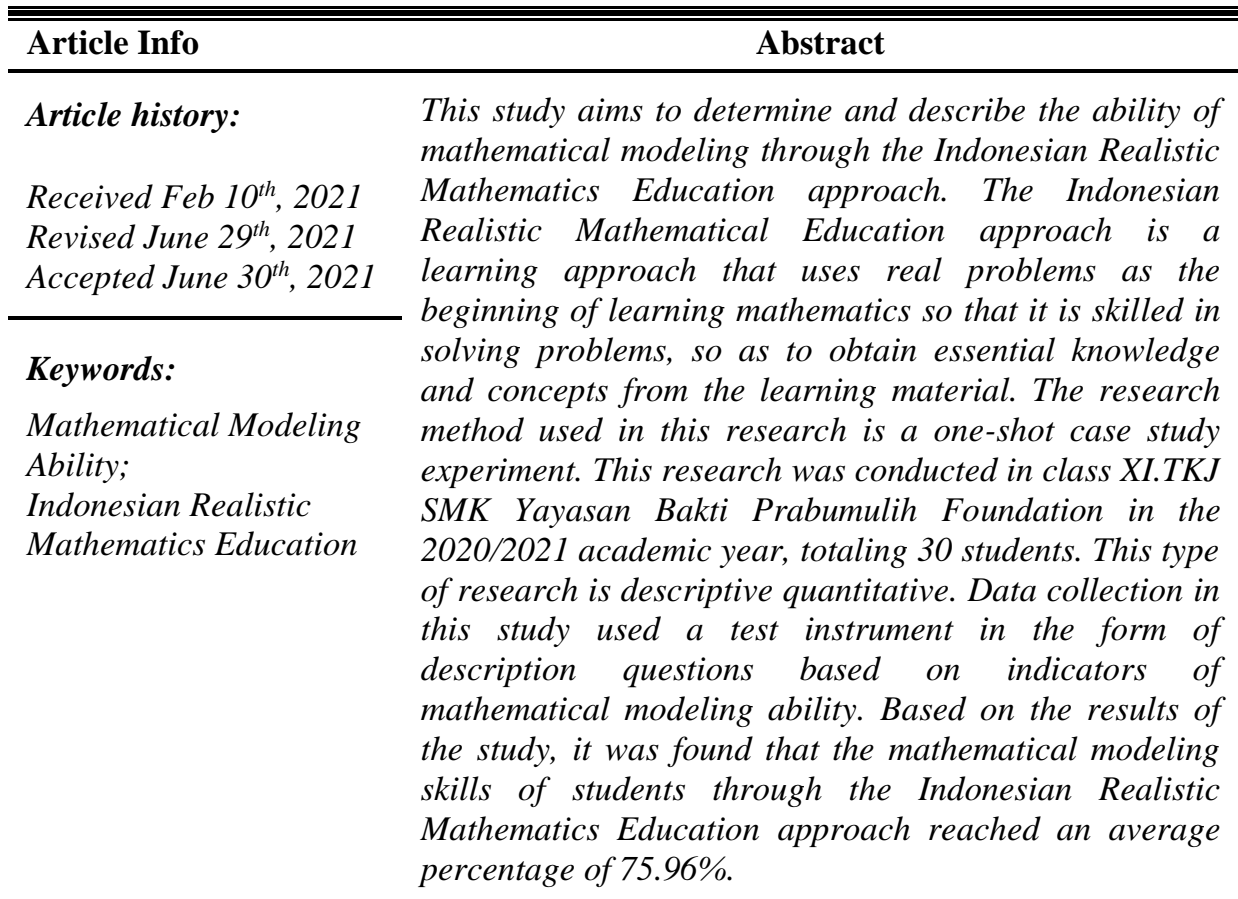

Kata Kunci:

Kemampuan Pemodelan Matematika;

Pendidikan Matematika Realistik Indonesia

\section{Abstrak}

Penelitian ini bertujuan untuk mengetahui dan mendesksripsikan kemampuan pemodelan matematika melalui pendekatan Pendidikan Matematika Realistik Indonesia (PMRI). Pendekatan Matematika Realistik Indonesia (PMRI) adalah suatu pendekatan pembelajaran yang menggunakan masalah nyata sebagai awal pembelajaran matematika agar terampil dalam memecahkan suatu masalah, sehingga memperoleh pengetahuan dan konsep esensial dari materi pembelajaran. Metode penelitian yang digunakan dalam 
penelitian ini adalah eksperimen one-shot case study. Penelitian ini dilakukan di kelas XI.TKJ SMK Yayasan Bakti Prabumulih tahun pelajaran 2020/2021 yang berjumlah 30 peserta didik. Jenis penelitian ini adalah deskripstif kuantitatif. Pengumpulan data dalam penelitian ini menggunakan instrumen tes berupa soal uraian berdasarkan indikator kemampuan pemodelan matematika. Berdasarkan hasil penelitian diperoleh bahwa kemampuan pemodelan matematika peserta didik melalui pendekatan Pendidikan Matematika Realistik Indonesia (PMRI) mencapai persentase rata-rata sebesar $75,96 \%$.

\section{PENDAHULUAN}

Matematika sangat erat hubungannya dengan kehidupan sehari-hari, Secara tidak sadar, kita sering menyelesaikan masalah sehari-hari dengan menggunakan matematika. Untuk menyelesaikan masalah sehari-hari yang berhubungan dengan matematika, peserta didik harus mempunyai kemampuan untuk memodelkan matematika (Andresen, 2009). Oleh sebab itu kemampuan pemodelan matematika sangat berperan penting dalam pembelajaran matematika. kemampuan pemodelan matematika adalah kemampuan peserta didik dalam menerjemahkan suatu permasalahan yang nyata dalam kehidupan sehari-hari ke dalam kalimat matematika (model matematika) (Pitriani, 2016).

Berdasarkan hasil laporan Nurfuadah (Nadia, 2013), menyatakan bahwa literasi matematika peserta didik Indonesia sangat rendah. Salah satu alasan yang diungkapkan adalah karena kurikulum pendidikan matematika di Indonesia belum menekankan pada komponen pemecahan masalah salah satunya yaitu kemampuan pemodelan matematika, melainkan pada hal-hal prosedural. Peserta didik dilatih menghapal rumus, tetapi kurang menguasai penerapannya dalam memecahkan masalah dan memodelkannya. Begitu juga hal yang terjadi di SMK Yayasan Bakti Prabumulih. Berdasarkan pengamatan saya di SMK Yayasan Bakti Prabumulih bahwa dalam pembelajaran, guru di kelas 
masih bersifat teacher centered, guru hanya memberikan materi pelajaran menggunakan metode ceramah, tugas, serta diskusi. Guru juga lebih sering menjelaskan soal-soal yang mudah kepada peserta didik, sehingga banyak peserta didik yang sulit dalam menerjemahkan suatu kalimat nyata ke dalam kalimat matematika khususnya pada soal cerita dan hal itu menyebabkan kebanyakan peserta didik kurang memahami soal sehingga menyebabkan peserta didik sulit membuat model matematika.

Menurut (Idris \& Silalahi, 2016) mengatakan bahwa kenyataannya guru di kelas selalu memberikan soal yang prosedural. Guru tidak pernah memberikan masalah pada pelajaran matematika dengan bentuk soal cerita sehingga hal tersebut membuat peserta didik tidak bisa memecahkan masalah dalam bentuk soal cerita. Hal ini menjadi suatu masalah bagi peneliti karena kemampuan peserta didik dalam menyelesaikan soal cerita sangat penting yang bisa diaplikasikan dalam kehidupan sehari-hari. Jika dalam kehidupan nyata mereka tidak bisa menyelesaikan masalah yang berkaitan dengan matematika, mereka akan mengalami kesulitan.

Dari penjelasan di atas terlihat bahwa Kemampuan Permodelan Matematika (KPM) mempunyai peranan yang sangat penting. Oleh karena itu harus dicari pembelajaran yang sesuai dengan tujuan untuk mencapai kemampuan ini. Adapun pembelajaran yang sesuai adalah pembelajaran dengan menggunakan pendekatan Pendidikan Matematika Realistik Indonesia (PMRI). Hal ini dikarenakan PMRI memiliki salah satu karakteristik menggunakan model.

Pendekatan PMRI adalah suatu teori pembelajaran yang bertitik tolak dari hal - hal yang real atau pernah dialami peserta didik, menekan keterampilan proses doing mathematics, berdiskusi, dan berkolaborasi dengan teman sekelas sehingga mereka dapat menemukan sendiri sebagai kebalikan dari (teacher telling) dan pada akhirnya menggunakan matematika untuk menyelesaikan masalah baik secara kelompok maupun individu (Zulkardi \& Putri, 2010). Pemodelan juga merupakan salah satu bagian penting dari sebuah pendekatan PMRI. 


\section{METODE PENELITIAN}

Metode penelitian yang dilakukan pada penelitian ini adalah penelitian deskriptif. Penelitian deskriptif adalah penelitian yang digunakan untuk mengetahui fenomena/perubahan yang ada terhadap aktivitas dari kejadian saat ini atau saat lampau (Asep, 2014). Peneliti menggunakan jenis penelitian ini untuk mengetahui kemampuan pemodelan matematika melalui pendekatan PMRI.

Penelitian ini dilaksanakan di SMK Yayasan Bakti Prabumulih pada semester ganjil tahun pelajaran 2020/2021. Subjek penelitian ini adalah peserta didik kelas XI.TKJ SMK Yayasan Bakti Prabumulih yang terdiri dari 30 peserta didik. Adapun instrumen penelitian yang digunakan yaitu Rencana Pelaksanaan Pembelajaran (RPP) dan Lembar Kerja Peserta Didik (LKPD) yang dibuat berdasarkan karakteristik PMRI, serta soal tes. Teknik pengumpulan data yang digunakan peneliti yaitu tes. Hasil akhir dari nilai tes tersebutlah yang menjadi tolak ukur kemampuan pemodelan matematika. Tes dilakukan untuk mengetahui kemampuan pemodelan matematika peserta didik. Penelitian ini dilaksanakan selama empat kali pertemuan.

\section{HASIL PENELITIAN DAN PEMBAHASAN}

Data diperoleh dari hasil tes pada tiap kali pertemuan terhadap 30 peserta didik kelas XI.TKJ SMK Yayasan Bakti Prabumulih yang diterapkan dengan menggunakan pendekatan PMRI pada materi program linear. Data yang diperoleh dari hasil penelitian tersebut berupa skor tiap indikator kemudian data skor tersebut direkapitulasi dan dipersentasekan berdasarkan tabel kriteria kemampuan pemodelan matematika. Dari tes yang diberikan pada pertemuan pertama, kedua dan ketiga, diperoleh skor rata-rata peserta didik yaitu 77,62 dan rata-rata skor ini dikategorikan baik. Di bawah ini adalah presentase skor rata-rata tes pada tiga kali pertemuan. 


\section{Tabel 1. KPM Berdasarkan Kategori}

\begin{tabular}{cccc}
\hline Nilai & Kategori & Jumlah & Persentase \\
\hline $84-100$ & Sangat Baik & 7 & 23,33 \\
$68-83$ & Baik & 17 & 56,66 \\
$52-67$ & Cukup & 5 & 16,67 \\
$36-51$ & Kurang & 1 & 3,33 \\
& Sangat & & \\
$0-35$ & Kurang & 0 & 0 \\
\hline Jumlah & Baik & 30 & 100 \\
\hline
\end{tabular}

Tabel 1. dapat dilihat bahwa setelah menggunakan pendekatan PMRI dalam pembelajaran matematika, peserta didik yang memiliki KPM dalam kategori sangat baik frekuensi sebanyak 7 dari 30 peserta didik atau sebesar 23\%, KPM dalam kategori baik memiliki frekuensi terbanyak yaitu 17 orang atau sebesar 56\%, pada kategori cukup terdapat 5 orang atau sebesar $16 \%$, dan ada kategori kurang terdapat 1 orang peserta didik atau sebesar 3\%. Pada sebagian kecil peserta didik yang termasuk kategori kurang, karena pada saat pembelajaran berlangsung peserta didik kurang mengikuti dan tidak memperhatikan apa yang didiskusikan dan hampir seluruh bagian soal tidak dapat diselesaikan dengan baik.

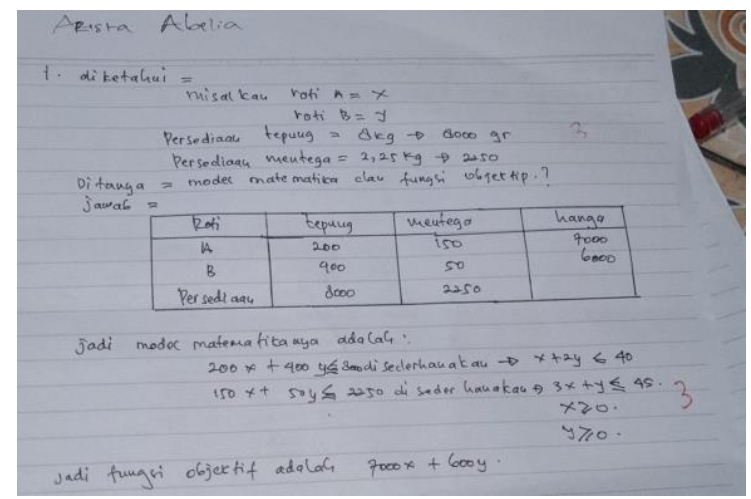

Gambar 1. Lembar Jawaban Tes Akhir KPM Peserta didik 
Gambar 1. menunjukkan bahwa soal nomor 1 memuat indikator memahami masalah dan menyiapkan model matematika. Berdasarkan Gambar 1 tersebut, peserta didik sudah dapat menuliskan diketahui dan ditanya dengan lengkap dan jelas. Peserta didik juga sudah dapat menyusun model matematika berdasarkan soal sehingga model matematika yang dibuat sudah mempresentasikan masalah yang diberikan sehingga pada soal nomor 1 peserta didik mendapatkan skor maksimal yaitu 6.

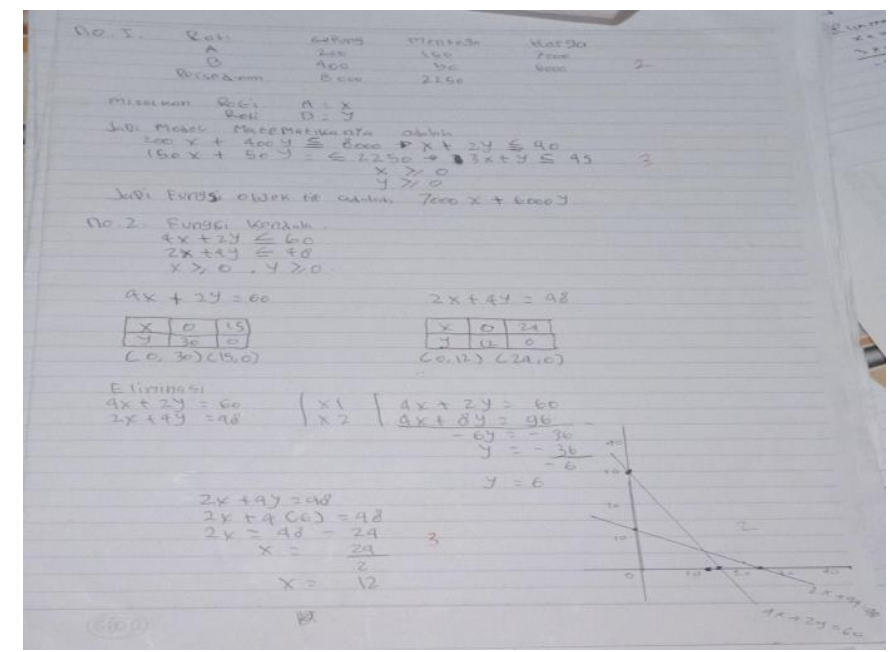

\section{Gambar 2. Lembar Jawaban Tes Akhir KPM Peserta Didik}

Gambar 2. menunjukkan soal nomor 1 yang memuat indikator memahami masalah dan menyiapkan model matematika. Untuk indikator pertama peserta didik sudah dapat menuliskan diketahui dan ditanya dengan jelas tetapi kurang lengkap kemudian, untuk indikator kedua peserta didik sudah mampu menyusun model matematika berdasarkan soal sehingga model matematika yang dibuat sudah mempresentasikan masalah yang diberikan, sehingga pada soal nomor 1 peserta didik mendapatkan skor maksimal yaitu 5. Dan pada soal nomor 2 yang memuat indikator menyelesaikan model matematika dan menafsirkan solusi. Untuk indikator ketiga peserta didik sudah dapat menyelesaikan model matematika yang terdapat dalam soal akan tetapi pada indikator keempat peserta didik tidak menyelesaikannya karena peserta didik tidak 
mengarsir grafik yang menunjukkan himpunan penyelesaian dari fungsi kendala sehingga untuk soal nomor 2 mendapatkan skor maksimal yaitu 5 .

\section{Tabel 2. KPM Berdasarkan Tiap Indikator}

\begin{tabular}{clcc}
\hline No & \multicolumn{1}{c}{$\begin{array}{c}\text { Indikator Kemampuan } \\
\text { Pemodelan Matematika }\end{array}$} & $\begin{array}{c}\text { Persentase Skor } \\
(\%)\end{array}$ & Kategori \\
\hline 1 & Memahami masalah & 88,15 & Baik \\
2 & Menyiapkan model matematika & 82,92 & Baik \\
3 & Menyelesaikan model & 69,11 & Cukup \\
& matematika & & \\
4 & Menafsirkan solusi & 66,67 & Cukup \\
\hline & $\quad$ Rata-rata persentase skor & 75,96 & Baik \\
\hline
\end{tabular}

Pembahasan mengenai hasil penelitian akan diuraikan berdasarkan pencapaian indikator kemampuan pemodelan matematika.

1. Memahami Masalah

Kemampuan peserta didik dalam menyelesaikan soal tes pada indikator memahami masalah telah mencapai persentase sebesar $88,15 \%$. Hal ini menunjukkan bahwa sebagian besar peserta didik sudah dapat memahami soal dengan baik, menentukan apa yang diketahui dan ditanya secara tepat.

Temuan di atas sejalan dengan hasil penelitian yang dilakukan oleh Mawaddah \& Anisah (2015) Peneliti menyatakan "bahwa tahap memahami masalah dengan cara menentukan apa yang diketahui dan ditanyakan dari sebuah masalah sangat baik". 


\section{Menyiapkan Model Matematika}

Kemampuan peserta didik dalam menyelesaikan soal tes pada indikator menyiapkan model matematika mencapai persentase sebesar $82,92 \%$. Dari hasil jawaban peserta didik, sudah banyak peserta didik dapat menyiapkan model matematika sesuai dengan informasi yang didapatkan dari soal. Hal ini ditandai dengan peserta didik mampu menerjemahkan kalimat yang diketahui ke dalam bentuk kalimat matematika atau peserta didik sudah mampu melakukan proses matematisasi dari kalimat nyata menjadi lambang-lambang matematika, hal ini sangat berkaitan dengan pendekatan PMRI karena salah satu karakteristik PMRI yaitu model digunakan dalam melakukan matematisasi secara progresif.

Menurut Lusiana (2019) seseorang tidak dapat menyelesaikan pemecahan masalah secara langsung, perlu melibatkan ekspresi atau simbol matematika sesuai konsep maupun konteksnya, karena menyusun model merupakan bagian dari tahapan penyelesaian masalah. Hal ini sejalan dengan hasil penelitian Khasanah (2015) yang mengatakan "Dalam menyelesaikan soal kemampuan pemecahan masalah masih ada beberapa peserta didik yang mengalami kesulitan dalam mentransformasikan kalimat ke dalam model matematika".

3. Menyelesaikan Model Matematika

Kemampuan peserta didik dalam menyelesaikan soal tes pada indikator menyelesaikan model matematika mencapai persentase sebesar 66,11\%. Dilihat dari hasil jawaban sebagian peserta didik sudah memahami strategi penyelesaian yang baik tetapi masih banyak juga peserta didik yang keliru dalam memilih strategi penyelesaian yang mengakibatkan kesalahan dalam menyelesaikan model matematika. Banyak juga peserta didik yang salah perhitungan sehingga menyebabkan hasil yang salah. Kesalahan-kesalahan tersebut sesuai dengan yang disampaikan oleh Ningrum (2013) bahwa "kesalahan yang dilakukan peserta didik dalam menyelesaikan soal di antaranya disebabkan peserta didik kurang teliti dalam menghitung atau menerapkan rumus". Khasanah (2015) juga menjelaskan dalam penelitiannya bahwa kesalahan peserta didik adalah tidak bisa menggunakan rumus dengan tepat, terjadi 
kesalahan dalam mensubstitusikan apa yang diketahui dalam soal ke dalam rumus dan kurangnya pemahaman peserta didik pada aspek pra syarat. Hal ini sejalan dengan hasil penelitian Ayu \& Rakhmawati (2019) yang menyimpulkan bahwa kemampuan peserta didik melaksanakan strategi penyelesaian soal cerita pada materi Sistem Persamaan Linear Dua Variabel (SPLDV) berada pada kategori cukup.

Adapun penelitian yang diakukan oleh (Akramunnisa \& Sulestry, 2016) menyatakan bahwa kemampuan menyelesaikan model matematika rendah. Menurut hasil penelitiannya kemampuan peserta didik dalam menyelesaikan model matematika tergolong rendah yang dapat disebabkan karena kemampuan dasar peserta didik dalam operasi hitung rendah.

4. Menafsirkan solusi

Kemampuan peserta didik dalam menafsirkan solusi mencapai persentase sebesar $66,67 \%$ lebih tinggi dibandingkan indikator menyelesaikan model matematika karena beberapa peserta didik sudah mampu mencoba menuliskan kesimpulan yang terdapat dari hasil. Sebagian peserta didik kurang teliti dan salah perhitungan pada tahap menyelesaikan model matematika sehingga berdampak dalam menafsirkan solusi yang diperoleh juga kurang tepat, meskipun terkadang peserta didik sudah memahami langkah-langkah menyelesaikan model matematika.

Hal ini sejalan dengan penelitian Mawaddah \& Anisah (2015) yang menyatakan bahwa nilai rata-rata untuk aspek menafsirkan solusi yang diperoleh lebih tinggi daripada nilai rata-rata melaksanakan rencana karena beberapa peserta didik mencoba menuliskan kesimpulan yang tidak tepat.

Kemampuan pemodelan matematika peserta didik untuk tiap indikator dapat dilihat pada Tabel 2. Skor tertinggi terdapat pada indikator pertama yaitu memahami masalah dengan persentase $88,15 \%$ dan ratarata terendah ada pada indikator ketiga yaitu menyelesaikan model matematika dengan rata-rata persentase $66,11 \%$.

Berdasarkan hasil tes yang dapat dilihat pada Tabel 1 secara keseluruhan skor rata-rata indikator kemampuan pemodelan matematika 
adalah 75,96\%. Dari pembahasan di atas menunjukkan bahwa pendekatan PMRI sangat baik untuk kemampuan pemodelan matematika peserta didik dalam menyelesaikan masalah yang salah satunya menyelesaikan masalah kontekstual pada materi Program Linier. Hal ini dapat dilihat dari sintaks pendekatan PMRI yang dilakukan guru pada proses pembelajaran yang mempunyai 5 fase yaitu: 1) fase memahami masalah kontekstual, pada fase ini guru memberikan masalah kontekstual yang ada pada LKPD; 2) fase menjelaskan masalah kontekstual, pada fase ini guru menjelaskan situasi dan kondisi soal dengan memberikan petunjuk/saran seperlunya (terbatas) terhadap bagian-bagian tertentu yang masih belum dipahami oleh peserta didik. Penjelasan ini hanya sampai peserta didik mengerti maksud soal; 3) menyelesaikan masalah kontekstual, pada fase ini guru meminta peserta didik untuk menyelesaikan masalah kontekstual dengan cara mereka sendiri, dengan 4) membandingkan dan mendiskusikan jawaban, pada fase ini guru menyediakan waktu dan kesempatan pada peserta didik untuk membandingkan dan mendiskusikan jawaban dari soal secara berkelompok. Untuk selanjutnya dibandingkan dan didiskusikan pada diskusi kelas; 5) menyimpulkan hasil diskusi, pada fase ini guru mengarahkan peserta didik menarik kesimpulan suatu prosedur atau konsep, dengan guru bertindak sebagai pembimbing, guru memotivasi peserta didik untuk menyelesaikan masalah dengan cara mereka sendiri melalui pertanyaan/petunjuk/saran yang diberikan.

Hasil penelitian ini sejalan dengan hasil penelitian Pitriani (2016) yang mengatakan bahwa dengan pembelajaran Realistic Mathematic Education (RME) dapat meningkatkan kemampuan pemodelan matematika peserta didik. Hasil penelitian Parlaungan juga mengatakan bahwa kemampuan pemodelan matematika dapat berkembang apabila dalam pembelajaran diarahkan dan disajikan permasalahan dalam bentuk kontekstual. Hal ini dapat difasilitasi melalui pendekatan PMRI, dimana salah satu karakteristik PMRI adalah penggunaan konteks atau permasalahan realistic sebagai titik awal pembelajaran matematika.

Hasil penelitian (Nindyakomalig et al., 2019) menyimpulkan bahwa kemampuan pemecahan masalah matematis peserta didik setelah diterapkan pendekatan PMRI lebih baik atau efektif dibandingkan 
sebelum diterapkan pendekatan PMRI. Hal ini menunjukkan bahwa seseorang dapat memecahkan suatu masalah jika dia bisa menyusun model dari permasalahan tersebut.

Dengan demikian, pembelajaran dengan menggunakan pendekatan PMRI dapat melatih kemampuan pemodelan matematika peserta didik di SMK Yayasan Bakti Prabumulih menjadi lebih baik.

\section{SIMPULAN}

Berdasarkan data hasil penelitian, dapat disimpulkan bahwa kemampuan pemodelan matematika peserta didik melalui pembelajaran Pendidikan Matematika Realitstik Indonesia (PMRI) di kelas XI.TKJ SMK Yayasan Bakti Prabumulih mencapai persentase sebesar 75,96\% dengan kategori baik.

\section{DAFTAR PUSTAKA}

Akramunnisa, \& Sulestry, A. I. (2016). Analisis Kemampuan Menyelesaikan Masalah Matematika Ditinjau Dari Kemampuan Awal Tinggi Dan Gaya Kognitif Field Independent ( Fi ). Pedagogy: Jurnal Pendidikan Matematika, 1(2), 46-56. http://journal.uncp.ac.id/index.php/Pedagogy

Andresen, M. (2009). Teaching To Reinforce The Bonds Between Modelling And Reflecting. Mathematical Applications And Modelling In The Teaching And Learning Of Mathematic, 73.

Ayu, N. S., \& Rakhmawati, F. (2019). Analisis Kemampuan Peserta

Didik Menyelesaikan Soal Matematika Bentuk Cerita Di Kelas Viii Mts. Negeri Bandar T.A. 2017/2018. AXIOM: Jurnal Pendidikan Dan Matematika, 8(1). https://doi.org/10.30821/axiom.v8i1.5451 Idris, \& Silalahi, K. (2016). Penerapan Pendekatan Pendidikan Matematika Realistik (PMR) untuk Meningkatkan Kemampuan Penyelesaian Soal Cerita. Jurnal EduMatSains, 1(1), 73-82. Khasanah, U. (2015). Kesulitan Menyelesaikan Soal Cerita Matematika Pada Peserta didik SMP. 
Lusiana, L. (2019). Pemecahan Masalah melalui Pemodelan Matematika dalam Aplikasi Kalkulus Integral. National Conference on Mathematics Education, November, 1-9.

Mawaddah, S., \& Anisah, H. (2015). Kemampuan Pemecahan Masalah Matematis Peserta didik Pada Pembelajaran Matematika dengan Menggunakag) di SMPn Model Pembelajaran Generatif (Generative Learning) di SMP. EDU-MAT: Jurnal Pendidikan Matematika, 3(2), 166-175. https://doi.org/10.20527/edumat.v3i2.644

Nindyakomalig, R., Gusmania, Y., \& Husna, A. (2019). Efektivitas Pendekatan Pmri Terhadap Kemampuan Pemecahan Masalah Matematis Peserta didik Kelas X Smkit Darussalam Boarding School. Phytagoras, $\quad$ 8(1), 23-31. https://www.journal.unrika.ac.id/index.php/jurnalphythagoras/article/ view/1774

Ningrum, L. S. (2013). Analisis Kemampuan Peserta Didik Menyelesaikan Soal Matematika Dalam Bentuk Cerita Pokok Bahasan Barisan Dan Deret Pada Peserta Didik Kelas Xii Sma AlIslam 3 Surakarta. 53(9), 1689-1699.

Pitriani. (2016). Kemampuan Pemodelan Matematika Dalam Realistic Mathematics Education (RME). 2(June), 65-82.

Zulkardi, \& Putri, R. I. I. (2010). Pengembangan blog support untuk membantu peserta didik dan guru matematika Indonesia belajar pendidikan matematika realistic Indonesia (PMRI). Jurnal Inovasi Perekayasa Pendidikan (JIPP), 2(1), 1-24. 